\title{
Innovation and firm value: An investigation of the changing role of patents, 1985-2007
}

\author{
Sharon Belenzon ${ }^{\mathrm{a}, 1}$, Andrea Patacconi ${ }^{\mathrm{b}, *}$ \\ a Fuqua School of Business, Duke University, USA \\ ${ }^{\mathrm{b}}$ University of Aberdeen Business School, UK
}

\section{A R T I C L E I N F O}

\section{Article history:}

Received 17 March 2010

Received in revised form 29 April 2013

Accepted 3 May 2013

Available online 16 June 2013

\section{JEL classification:}

O31

032

016

Keywords:

Firm value

Patent portfolio valuation

Patent policy

\begin{abstract}
A B S T R A C T
This paper examines how the relationship between firm value and patent-based indicators of inventive activity has changed over time. We use data from more than 33,000 mergers and acquisitions deals between 1985 and 2007, and distinguish between American (USPTO) and European (EPO) patents. Our results indicate that over time EPO patents have become the dominant indicator of innovative activity, while USPTO patents have no effect on firm value near the end of the sample period. The results are robust to controlling for citations and are especially strong for small firms, for firms operating in the drug and chemical industries, and when target and acquiring firms operate in different industries or countries.
\end{abstract}

(c) 2013 Elsevier B.V. All rights reserved.

\section{Introduction}

In evaluating potential targets for mergers and acquisitions (M\&A), acquiring firms must take several factors into account: the value of the target company's tangible and intangible assets, the potential for synergies between the merging firms, cost-of-capital and tax considerations, and more. A factor that has become increasingly important in recent years is intellectual property. A large patent portfolio can positively influence a firm's valuation in M\&A for a number of reasons. Patents are legal titles that grant their owners a temporary monopoly power over the use of an invention. Thus, they can be used to enforce exclusivity, to extract licensing income, or as a bargaining chip in negotiations. We refer to these uses of intellectual property as the monopoly or legal value of patents. Patents can also be correlated with firm value because they provide information about the quality of inventions and overall “corporate technological strength" (Long, 2002; Narin et al., 1987). Patenting is expensive, thus only inventions that are deemed sufficiently valuable are patented. Moreover, examiners must check

\footnotetext{
* Corresponding author at: University of Aberdeen Business School, Edward Wright Building, Dunbar Street, Aberdeen AB24 3QY, UK. Tel.: +44 01224273423.

E-mail addresses: sharon.belenzon@duke.edu (S. Belenzon), a.patacconi@abdn.ac.uk (A. Patacconi).

1 Address: Duke University: The Fuqua School of Business, 100 Fuqua Drive, Durham, NC 27708, USA. Tel.: +1 9196607845.
}

that inventions satisfy minimum standards of novelty and nonobviousness. More broadly, large patent portfolios may suggest that firms are well-managed and possess valuable R\&D capabilities. Thus, large patent portfolios can signal technological strength.

However, recent patent and administrative reforms have most likely affected both the monopoly and the informational (or "quality-signaling") value of patents. There is a broad consensus among academics and practitioners that patent protection in most OECD countries has been considerably strengthened since the 1980s (Jaffe and Lerner, 2004; Lerner, 2002). Important steps in this direction have been the creation in 1982 of a "pro-patent" Court of Appeals in the U.S., the subsequent upward harmonization of intellectual property protection standards via international agreements, and the extension of patentability to new subject matter such as biotechnology and software (in the U.S., also business methods). ${ }^{2}$ Thus, the monopoly value of patents has most likely increased in the last three decades.

At the same time, patent examination standards appear to have declined. Jaffe and Lerner (2004) provide several examples of obvious or non-novel ideas that were granted patent protection, including a "Method to Swing on a Swing", the "Sealed Crustless Sandwich", Rambus's divisional applications on developments of

\footnotetext{
${ }^{2}$ Recent judicial decisions, however, have arguably restricted the range of business methods that are patentable in the U.S.
} 
its DRAM technology, and, perhaps more controversially, one-click business models. Importantly, the decline in examination standards appears to have been pronounced especially in the U.S., due to a number of institutional, legal and cultural factors (Guellec and van Pottelsberghe de la Potterie, 2007; Jaffe and Lerner, 2004). Thus, patent "quality" (broadly intended to encompass both the technological and value dimensions of patented inventions) may have declined more in the U.S. than in other major jurisdictions.

Motivated by these considerations, the present paper examines how the relationship between firm value and patent-based indicators of inventive activity has changed in the last three decades. We use data from more than 33,000 mergers and acquisitions deals between 1985 and 2007, and distinguish between American (USPTO) and European (EPO) patents. We find that while the effect of EPO patents on acquisition value has remained essentially stable over this time period, the effect of USPTO patents has declined substantially and is essentially zero near the end of the sample period. ${ }^{3}$ Given that patent protection rights were strengthened during this time period, our results suggest that an increasing number of USPTO patents were granted for inventions that had little or no economic or technological value. USPTO patents seem to be losing their role as signals of firms' inventive efforts and value.

The robustness of our findings is probed in several ways. Qualitatively similar results are obtained when patents are weighed by citations, although citation-weighing generally increases the importance of USPTO patents. This is expected since citations proxy for patent quality and patent quality may to some extent be observed by the acquiring firm (Hall et al., 2005). Our findings are driven by patents owned by small firms. This is also not surprising given that intellectual property and signaling considerations are arguably most important in the start-up phase of a firm's life. There is also substantial heterogeneity across industries. The decline in the importance of USPTO patents is most evident in drugs and chemicals, while no such decline is found in computers and electronics. ${ }^{4}$ We find similar results in biotechnology and more traditional segments of the drug and chemical industries. This does not support the presumption that U.S. patent quality declined most sharply in new technology fields (Hall, 2007; Merrill et al., 2004). Finally, EPO patents appear to have become more important over time, relative to USPTO patents, when acquiring and target firms belong to different industries or operate in different countries. We conjecture that, in these deals, because acquiring firms may find it more difficult to evaluate a target firm's technology, EPO patents may be perceived as "safer." The EPO system may be providing some quality certification - a certification which becomes more important as uncertainty and informational asymmetries grow (Akerlof, 1970).

The remainder of the paper is organized as follows. The next section discusses some features of the American and European patent systems that motivate our empirical analysis. Sections 3 and 4 describe the data and econometric specification. Section 5 reports the results. Section 6 concludes.

\section{Background and predictions}

\subsection{The changing institutional environment}

There is widespread consensus among academics and practitioners that, starting from the early 1980s, various patent and

\footnotetext{
${ }^{3}$ However, we also find a large increase in USPTO patent valuations in the late 1990s. This increase was most likely a consequence of the exuberance that characterized of the dot-com years.

${ }^{4}$ In software, a technology area where patenting has often been regarded as dubious, neither USPTO nor EPO patents matter for value in any of the sample periods.
}

administrative reforms have led to a strengthening of the legal value of patents. In the U.S., a key step in this direction was the creation in 1982 of a specialized Court of Appeals of the Federal Circuit (CAFC). Although the stated objective of Congress was to provide uniformity in patent litigation cases, the court soon demonstrated a "pro-patent" disposition (Mazzoleni and Nelson, 1998; Merges, 1992). Specifically, the court was found to uphold in appeal a larger proportion of decisions favorable to the patent holder, to reverse a larger proportion of decisions unfavorable to patent holder, and to substantially increase the rate of preliminary injunctions, compared to the previous system (Gallini, 2002; Lanjouw and Lerner, 2001). The definition of patentable subject matter was also broadened to include emerging new fields such as biotechnology and software, and patent duration was lengthened. Several countries followed the U.S. example, which led over time to an upward harmonization of intellectual property protection standards (Guellec and van Pottelsberghe de la Potterie, 2007; Lerner, 2002).

The strengthening of the legal value of patents gave firms powerful incentives to seek patent protection (Hall and Ziedonis, 2001; Kortum and Lerner, 1999). Patent applications nearly tripled between 1980 and 2000 in the U.S., with Europe and Japan following suit. But as patents became more powerful legal weapons, concerns about the ease with which they were granted began to grow. Observers noted that way too often patents were granted for ideas that were neither novel nor non-obvious. Some - most notably Jaffe and Lerner (2004) - went as far as to argue that lower standards could endanger innovation and progress because, if applicants could get patents for obvious or existing ideas, then patents could used to harass, seek compensation from, or even shut down legitimate businesses. Overwhelmingly, however, criticism about declining patentability standards has been directed toward the American system. Several arguments underpin the belief that examination standards are lower (and, until quite recently at least, have been getting worse) in the U.S. than in Europe or Japan.

First, the USPTO is severely understaffed relative to other major patent offices. Guellec and van Pottelsberghe de la Potterie (2007) estimate that "both the incoming workload of examiners (number of claims filed per examiner) and their output (number of claims granted per examiner) is three to four times higher at the USPTO than at the EPO" (p. 201). Thus USPTO examiners spend considerably less time than EPO examiners on each claim. Retention of experienced personnel has also proved to be particularly difficult at the USPTO, due to a combination of relatively low salaries and attractive outside options. ${ }^{5}$ Guellec and van Pottelsberghe de la Potterie conclude that decisions at the EPO tend to be based on a more careful and expert assessment of the prior art than at the USPTO, which might explain the much higher rejection rates in Europe. ${ }^{6}$

Second, USPTO examiners appear to face stronger pressures to accept rather than reject applications than examiners in Europe or Japan. One reason is that, by transforming the USPTO in a userfee funded entity, the 1990 Omnibus Act may have promoted

\footnotetext{
5 According to Mejer and van Pottelsberghe de la Potterie (2011), turnover of employees at the USPTO is about $33 \%$, compared to just $3 \%$ at the EPO.

6 Quillen and Webster (2001) estimate that the patent approval rate for the USPTO when corrected for continuing applications is in the range of 95-97\%, substantially higher than for the EPO or JPO. Jaffe and Lerner (2004) also show that successful USPTO applications have risen in the period between 1987 and 1998 twice as much as 'important' inventions that were granted in all three of the world's major patent jurisdictions (the USPTO, EPO, and JPO). They argue that this finding is "hard to explain in any manner other than declining standards in the U.S. PTO, producing an ever-growing proportion of U.S. patents the patent-holders themselves did not think merited patenting elsewhere" (p. 143). Finally, Gallini (2002) notes that if the time series of Kortum and Lerner (1999) is extended to include the second half of the 1990s, Kortum and Lerner's conclusion that the U.S. did not become an increasingly attractive destination for foreign inventors is tempered, thus "lending some support for the 'friendly court' hypothesis" (p. 138)
} 
a "customer-friendly" mentality. Jaffe and Lerner (2004) provide several examples illustrating the dysfunctional effect of such a mentality. Most importantly, USPTO examiners are rewarded according to how fast they process applications. However, since applicants can modify and appeal initially rejected patents, rejections tend to be very time-consuming. Thus, USPTO examiners have strong financial incentives to accept rather than reject applications.

Third, from its inception the EPO allows third parties to challenge claims in a patent for nine months after the patent is granted. This permits additional prior art references to be submitted and allows further verification of the patentability conditions (Mejer and van Pottelsberghe de la Potterie, 2011). In the U.S., by contrast, a similar post-grant review process has only recently been introduced with the 2011 America Invents Act.

Fourth, until quite recently, court decisions have tended to weaken U.S. patentability standards. The CAFC established, for instance, that prior publication obviates novelty only when all the features of an invention have been revealed by a single prior publication, ${ }^{7}$ and established "the reasonable expectation of success" as a lower standard of non-obviousness ${ }^{8}$ (Barton, 2000; Lesser and Lybbert, 2004). There are also fewer limitations on patentable subject matters in the U.S. than in Europe. Inventions in the areas of software, business methods and genetics, for instance, are generally patentable in the U.S. but not in Europe. The explosion of patent activity in new technology areas has been viewed with particular concern by critics of the USPTO. Examination standards appear to have been too low in these fields (at least initially), due to inexperience on the part of examiners, lack of adequate written prior art documents, and court decisions (Merrill et al., 2004; Hall, 2007).

Last but not least, patenting costs are much lower in the U.S. than in Europe or Japan. van Pottelsberghe de la Potterie and François (2009) estimate that an EPO patent that is renewed for 20 (10) years in 13 member states costs almost 9 (4.6) times as much as a USPTO patent. An obvious effect of low patenting costs is to encourage low-value applications and increase the variance of the patent quality distribution by stretching its bottom tail. Perverse feedback effects can also arise, with low patenting costs exacerbating workload problems. ${ }^{9}$ Moreover, firms may, when they have a choice, start filing strategically, by first applying for USPTO patents and only subsequently, if the inventions turn out to be valuable, for the more expensive EPO patents. Combined, these effects could lead over time to a wider quality gap between EPO and USPTO patents. ${ }^{10}$

\subsection{Patent portfolio evaluation in MEA: the effect of institutional change}

From a financial perspective, the firm can be viewed as a portfolio of investment projects; thus the value of the business as a whole can be computed as the net present value of the cash flows it generates. As mentioned in the Introduction, patents (and by extension patent portfolios) can be positively correlated with firm valuations

\footnotetext{
7 Studiengesellschaft Kohle v. Dart Indus. Inc., 726 F.2d 724 (Fed. Cir. 1984).

8 Amgen, Inc. v. Chugai Pharmaceutical Co., 927 F.2d 1200 (Fed. Cir. 1991).

${ }^{9}$ How changes in the patent fee structure can improve the patent quantity-quality tradeoff is an important topic in policy debates, especially after the USPTO raised its fees in 2004. See Guellec and van Pottelsberghe de la Potterie for a discussion (2007, pp. 212-213).

10 In general, firms have the possibility to seek patent protection in multiple countries, but will only use this possibility for inventions that they deem sufficiently valuable to justify the extra expense. USPTO and EPO patents are in this respect arguably different because, while a USPTO patent may or may not be part of a patent family comprising a number of equivalent patents in different countries, an EPO patent is almost always the result of a decision that the invention is worth the expense of seeking protection in multiple countries, as a single national application would otherwise be less expensive (we thank an anonymous referee for pointing this out to us).
}

because (i) they establish exclusionary rights on patented inventions and (ii) provide useful signals about the quality of patented inventions and overall corporate technological strength.

Several studies confirm the usefulness of patent statistics as indicators of firms' inventive efforts and value (e.g., Griliches, 1990). Deng et al. (1999) find that the number of patents granted to a firm in a given year and patent citation measures (forward citations and "science link") are strongly associated with subsequent market-to-book ratios. Positive associations between firm value and citation-weighed patent indexes are also found by Bloom and Van Reenen (2002), Hall et al. (2005) and Belenzon (2012), among many others. Pakes (1985) demonstrates that an unexpected increase in the number of patents granted to a firm is associated with a large change in market value. Using a comprehensive survey instrument, Gambardella et al. (2008) directly ask for information about the perceived value of patents, rather than trying to infer patent values using estimation techniques. They report very high estimates, with the average patent value above EUR10 million, and a median of EUR650 thousand. Lastly, in a sample of pharmaceutical firms, Narin et al. (1987) find that patent counts are highly correlated with several measures of corporate technological strength such as the number of new drugs registered, important new drugs approved, scientific articles published, and expert opinions of corporate technical strength.

In this paper, we focus on the contribution of patent portfolios to the valuation of target firms in M\&A deals. In evaluating patent portfolios, acquiring firms must take several factors into account. Factors frequently mentioned by practitioners include: (i) changing market conditions and technology cycles, (ii) the level of novelty of the patented inventions, (iii) the strength and breadth of exclusionary rights, (iv) the difficulty of inventing around, (v) the risks of patent disclosure, (vi) a firm's overall portfolio position (including the potential for further patents), and (vii) bargaining potential (Wilson, 2007). Moreover, in M\&A the value of potential synergies between acquiring and target firms can be partly incorporated into the target firm's price (Slusky and Caves, 1991). Thus, patent portfolio valuations in M\&A may also reflect firm-specific and dealspecific factors, not just the value of the patent portfolio in some absolute sense.

The previous discussion suggests that patent reforms have affected both the level of novelty of the patented inventions and the strength and breadth of exclusionary rights (points (ii) and (iii) in the classification above). We put forward two potentially conflicting hypotheses. The first one states that, because patents have become more potent legal weapons, the effect of both USPTO and EPO patents on corporate valuations has grown stronger in recent times.

H1 (Strengthening of patent protection rights). The relationship between firm value and USPTO and EPO patents has grown stronger in recent times.

The second hypothesis states that, because patent quality appears to have declined more in the U.S. than in Europe, EPO patents may have become over time a more reliable indicator of technological strength than USPTO patents. Thus, the effect of EPO patents on acquisition value in M\&A should have become stronger over time, relative to the effect of USPTO patents. Note that it is possible that the quality of USPTO patents may have declined so much as to completely outweigh the potential benefits of stronger patent protection rights. Thus, in contrast to what suggested in Hypothesis 1 , the relationship between USPTO patents and firm value may have grown weaker, not stronger, over time.

H2 (Declining USPTO patent quality). Over time, EPO patents have become more strongly related to firm value than USPTO patents. 
Two additional points are worth emphasizing. First, as discussed above, patent quality in the U.S. may have declined more in new technology areas such as biotechnology, software and business methods than in more traditional areas (Barton, 2000; Hall, 2007). Thus, changes in the importance of USPTO patents over time may not be uniform across sectors. We will distinguish between different technology sectors in the empirical part.

Second, because the economic significance of patents varies tremendously, simple patent counts may be very noisy proxies for the value of a firm's technology. In the empirical part, we will use forward citations to control for the quality of patented inventions. ${ }^{11}$ Because our discussion suggests that USPTO patents are more heterogeneous in their quality than EPO patents (and, in particular, that they exhibit a longer tail at the lower end of the quality distribution), we expect citation-weighing to strengthen especially the effect of USPTO patents.

\section{Data}

This paper combines data from three sources: (i) M\&A data from Thomson SDC Platinum, (ii) information on patents from the United States Patent and Trademark Office (USPTO), and (iii) information on patents from the European Patent Office (EPO).

We drop M\&A deals that do not report information on value, net total assets and acquired stakes. We also drop deals where the target firm is not from an OECD country, because patent law may vary substantially between developed and developing countries. This leaves us with 30,306 deals. 40\% of the targets are American, 20\% are British, $7 \%$ are Japanese, and the remaining are from other West European countries. We match these firms to our patent datasets. Prior to the acquisition completion year, 4,643 firms have at least one patent in the USPTO or EPO.

Table 1 summarizes descriptive statistics for the main variables used in our analysis. Firm value is computed as the ratio between transaction value and acquired stakes. The average target firm is valued at \$228 million, has \$118 million in total assets, generates $\$ 138$ million in annual sales, and makes $\$ 27$ million in profits. Two separate patent stocks are constructed: one for USPTO patents and another for EPO patents. We include only patents that are granted prior to the acquisition completion year. Stocks are computed using the perpetual inventory method with a depreciation rate of 15 percent. To control for patent quality, we also construct citationweighed stocks by weighing each patent by the number of citations it receives (excluding self-citations) divided by the average number of citations received by all other patents that are granted by the same patent office in the same year. For each patent, we include only citations from other patents that are granted by the same patent office. That is, for USPTO patents, we only include citations from USPTO patents, and for EPO patents we only include citations from EPO patents. Finally, we construct an aggregate patent measure - total patent stock - which is simply the sum of USPTO and EPO patent stocks for each firm. The average patenting firm (a firm with at least one patent from the USPTO or EPO) has a stock of 14 USPTO patents (a median of 3 ), and 8 EPO patents (a median of 1 ).

\footnotetext{
11 Since the landmark work of Trajtenberg (1990), citation-weighed patent indexes have been shown to be strongly correlated with the social value of innovations (Trajtenberg, 1990), peer evaluation of their technical importance (Albert et al., 1991), renewal decisions (Harhoff et al., 1999; Thomas, 1999), and firm value (Belenzon, 2012; Bloom and Van Reenen, 2002; Deng et al., 1999; Hall et al., 2005; Hirschey and Richardson, 2004). Hall et al. (2005), in particular, find that investors are able to accurately forecast the expected value of patented inventions, as it is later confirmed by future citations. An alternative way to control for patent quality would have been to estimate the private value of patents using annual renewal fees, as in Schankerman and Pakes (1986).
}

Since our focus is on how the relationship between patenting and acquisition value has changed over time, Table 2 presents descriptive statistics across time periods. The sample includes both patenting and non-patenting target firms. We split the sample into six time periods. Average firm value is quite stable over time. Average value is $\$ 233$ million for the deals completed in the period $1985-1990$, and $\$ 249$ million for the deals completed in the period 2005-2007. On the other hand, there is a substantial rise in Tobin's $q$ - the ratio between value and assets - over time. Average Tobin's $q$ is 3.4 for deals completed in 1985-1990, and is 4.9 for deals completed in 2005-2007. Thus intangible assets such as knowledge appear to have become more important over time.

Table 3 examines how key characteristics of target firms have changed over time. On average, $92 \%$ of patenting firms have at least one USPTO patent, and $72 \%$ have at least one EPO patent. Over time, the share of firms that patent in the USPTO declines but remains very high while the share of firms that patent in the EPO increases substantially from $56 \%$ in 1985 to about $77 \%$ in 2007 . There is a sharp increase in acquisition value in the period 1995-1998, but these high values subsequently return to the overall sample mean. Thus, there is no clear pattern regarding how firm value in these acquisition deals has changed over time. Tobin's $q$, on the other hand, increases substantially over time, albeit in a non-monotonic way (it also peaks in 1998). The share of non-American acquisitions also changes substantially over time (not reported in a table). In the whole sample $40 \%$ of the acquisitions involve American targets, yet this figures falls from around 69\% in 1985 to about a quarter of the deals in 2007. We discuss how this issue may affect the interpretation of our finding in the next section and when presenting the estimation results.

A fact that emerges clearly from our statistics is that valuations were very high during the 1995-1998 period. The most likely explanation for these high valuations is the exuberance that affected investors and stock markets during the dot-com bubble years. This bubble started in March 1995 with the excitement occasioned by Netscape's initial public offering, and terminated in 2000-2001 with the collapse of the NASDAQ Composite index (however, the American economy started losing speed since 1999). To account for possibly inflated corporate valuations during this period, in the rest of the analysis (as in Table 1), we will report separate estimations for the periods 1995-1998 and 1999-2001, which correspond to the boom and bust of the dot-com bubble.

\section{Econometric analysis}

We estimate the following specification for the value of target firms, both for the whole sample and for different time periods. ${ }^{12}$

$$
\begin{aligned}
\ln \text { Value }_{i t}= & \beta_{0} \ln \text { Assets }_{i t}+\beta_{1} \ln \left(1+\text { PatUS }_{i t-1}\right) \\
& +\beta_{2} \ln \left(1+\text { PatEU }_{i t-1}\right)+\tau_{t}+\eta_{i}+c_{c}+\varepsilon_{i} .
\end{aligned}
$$

Value $_{i t}$ is the value of target firm $i$ at acquisition completion year $t$ and is computed as transaction value over acquired equity. Assets $_{i t}$ is total net assets. PatUS $S_{i t-1}$ and PatEU $_{i t-1}$ are, respectively, target firm i's USPTO and EPO patent stocks prior to the acquisition completion year. $\tau_{t}, \eta_{i}$ and $c_{c}$ are complete sets of dummies for acquisition completion years, two digit target industry SIC codes, and target country. $\varepsilon_{i}$ is an iid error term. Our main interest is the way the coefficients $\beta_{1}$ and $\beta_{2}$ change over time. We investigate this in two ways: by interacting USPTO and EPO patent stocks with period dummies, and by estimating separate specifications for different time periods. Because changes in the quality of USPTO and

\footnotetext{
12 Lerner (1995) estimates a similar specification.
} 
Table 1

Summary statistics for main variables.

\begin{tabular}{|c|c|c|c|c|c|c|}
\hline \multirow[t]{2}{*}{ Variable } & \multirow[t]{2}{*}{ \# acquisitions } & \multirow[t]{2}{*}{ Mean } & \multirow[t]{2}{*}{ Std. dev. } & \multicolumn{3}{|c|}{ Distribution } \\
\hline & & & & 10th & 50th & 90th \\
\hline Target value (\$, mm) & 30,306 & 228 & 1,102 & 5 & 60 & 576 \\
\hline Net assets $(\$, \mathrm{~mm})$ & 30,306 & 118 & 1,890 & 7 & 30 & 281 \\
\hline Tobin's $q(\$, \mathrm{~mm})$ & 30,306 & 4.0 & 4.9 & 0.7 & 2.1 & 10.2 \\
\hline Sales $(\$, \mathrm{~mm})$ & 26,245 & 138 & 197 & 4 & 52 & 416 \\
\hline Profits $(\$, \mathrm{~mm})$ & 21,714 & 27 & 64 & -2 & 7 & 79 \\
\hline$\%$ of share acquired & 30,306 & 0.58 & 0.42 & 0.04 & 0.71 & 1 \\
\hline Total patent stock, count & 4,643 & 22 & 194 & 0.7 & 4 & 42 \\
\hline Total patent stock, cite & 4,643 & 21 & 161 & 0.4 & 4 & 43 \\
\hline USPTO patent stock, count & 4,643 & 14.4 & 142.9 & 0 & 2.6 & 25.5 \\
\hline USPTO patent stock, citation-weighed & 4,643 & 13.9 & 98.6 & 0.2 & 2.0 & 27.9 \\
\hline EPO patent stock, count & 4,643 & 7.7 & 54.3 & 0.5 & 1.1 & 14.5 \\
\hline EPO patent stock, citation-weighed & 4,643 & 7.5 & 64.8 & 0.3 & 0.9 & 13.5 \\
\hline
\end{tabular}

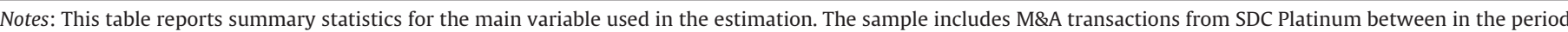

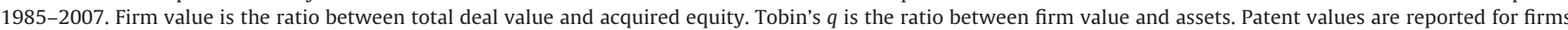

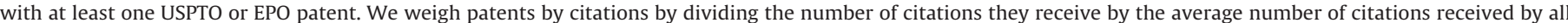
patents that are granted by the same patent office in the same year. Robust standard errors are in brackets.

Table 2

Summary statistics for main variables for different time periods.

\begin{tabular}{|c|c|c|c|c|c|c|c|c|c|c|c|c|}
\hline \multirow[t]{2}{*}{ Variable } & \multicolumn{2}{|c|}{$\begin{array}{l}1985-1990 \\
(4,770 \text { deals })\end{array}$} & \multicolumn{2}{|c|}{$\begin{array}{l}\text { 1991-1994 } \\
\text { (6,287 deals) }\end{array}$} & \multicolumn{2}{|c|}{$\begin{array}{l}1995-1998 \\
(6,287 \text { deals })\end{array}$} & \multicolumn{2}{|c|}{$\begin{array}{l}\text { 1999-2001 } \\
\text { (4,890 deals) }\end{array}$} & \multicolumn{2}{|c|}{$\begin{array}{l}2002-2004 \\
(2,694 \text { deals })\end{array}$} & \multicolumn{2}{|c|}{$\begin{array}{l}2005-2007 \\
(5,420 \text { deals })\end{array}$} \\
\hline & Mean & Median & Mean & Median & Mean & Median & Mean & Median & Mean & Median & Mean & Median \\
\hline Firm value $(\$, \mathrm{~mm})$ & 233 & 72 & 194 & 37 & 222 & 64 & 262 & 73 & 204 & 56 & 249 & 74 \\
\hline Net assets $(\$, \mathrm{~mm})$ & 108 & 37 & 154 & 19 & 92 & 31 & 103 & 33 & 110 & 38 & 126 & 29 \\
\hline Tobin's $q(\$, \mathrm{~mm})$ & 3.4 & 2.1 & 3.7 & 1.9 & 3.9 & 2.1 & 4.4 & 2.1 & 3.0 & 1.5 & 4.9 & 2.7 \\
\hline Sales $(\$, \mathrm{~mm})$ & 167 & 74 & 123 & 40 & 120 & 42 & 143 & 55 & 146.4 & 60.3 & 141.8 & 58.2 \\
\hline Profits (\$, mm) & 42 & 15 & 23 & 5 & 27 & 7 & 27 & 8 & 22.9 & 5.2 & 23.5 & 5.4 \\
\hline$\%$ of share acquired & 42.9 & 78.1 & 61.3 & 56.3 & 54.7 & 55.3 & 1.0 & 65.7 & 56.5 & 51.3 & 58.2 & 62.3 \\
\hline USPTO patent stock, count & 18.5 & 3.9 & 12.4 & 3.1 & 10.5 & 2.7 & 11.9 & 2.0 & 29.4 & 1.9 & 9.8 & 1.6 \\
\hline USPTO patent stock, citation-weighed & 18.3 & 3.8 & 14.0 & 2.5 & 13.0 & 2.2 & 11.0 & 1.4 & 21.6 & 1.1 & 8.0 & 1.1 \\
\hline EPO patent stock, count & 7.3 & 0.4 & 8.1 & 1.4 & 6.0 & 1.2 & 7.5 & 1.0 & 12.0 & 1.2 & 7.5 & 1.3 \\
\hline EPO patent stock, citation-weighed & 6.9 & 0.3 & 7.6 & 1.1 & 5.5 & 1.0 & 7.1 & 0.8 & 13.5 & 1.0 & 7.4 & 1.2 \\
\hline
\end{tabular}

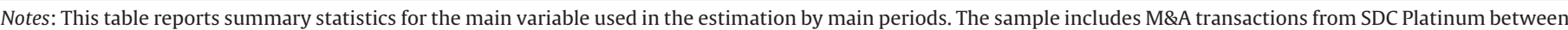

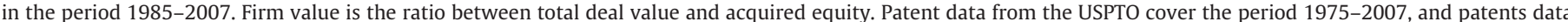

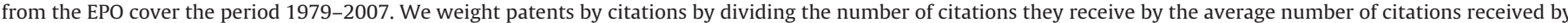
all patents granted in the same year.

Table 3

Patenting firms across years.

\begin{tabular}{|c|c|c|c|c|c|}
\hline Year & \# deals & Firm value & Tobin's $q$ & \% Patent in the USPTO & \% Patent in the EPO \\
\hline 1985 & 52 & 388.1 & 2.3 & 100.0 & 55.8 \\
\hline 1986 & 98 & 510.8 & 3.0 & 98.0 & 62.2 \\
\hline 1987 & 134 & 322.6 & 3.1 & 98.5 & 62.7 \\
\hline 1988 & 187 & 319.1 & 2.4 & 95.2 & 62.0 \\
\hline 1989 & 227 & 381.2 & 3.1 & 95.2 & 66.1 \\
\hline 1990 & 216 & 393.4 & 3.1 & 94.0 & 72.2 \\
\hline 1991 & 189 & 275.7 & 2.9 & 91.5 & 69.8 \\
\hline 1992 & 186 & 278.8 & 3.0 & 94.1 & 75.8 \\
\hline 1993 & 222 & 278.0 & 3.9 & 89.2 & 73.9 \\
\hline 1994 & 280 & 254.9 & 3.6 & 94.3 & 71.4 \\
\hline 1995 & 253 & 466.7 & 4.2 & 96.0 & 71.1 \\
\hline 1996 & 282 & 312.6 & 3.9 & 94.3 & 69.5 \\
\hline 1997 & 285 & 390.3 & 5.0 & 96.1 & 73.3 \\
\hline 1998 & 86 & 639.5 & 4.3 & 94.2 & 67.4 \\
\hline 1999 & 336 & 275.3 & 4.2 & 90.8 & 73.8 \\
\hline 2000 & 211 & 306.2 & 4.1 & 92.4 & 73.5 \\
\hline 2001 & 137 & 213.0 & 3.3 & 93.4 & 74.5 \\
\hline 2002 & 229 & 296.4 & 2.9 & 90.8 & 73.8 \\
\hline 2003 & 203 & 179.8 & 2.8 & 91.6 & 77.8 \\
\hline 2004 & 30 & 598.9 & 4.0 & 93.3 & 73.3 \\
\hline 2005 & 246 & 308.0 & 4.6 & 85.0 & 76.8 \\
\hline 2006 & 357 & 342.7 & 3.9 & 82.6 & 78.2 \\
\hline 2007 & 197 & 358.1 & 3.6 & 83.2 & 76.6 \\
\hline Total & 4,643 & 329.8 & 3.6 & 91.9 & 72.1 \\
\hline
\end{tabular}

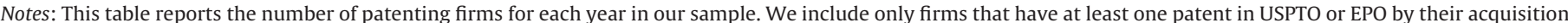

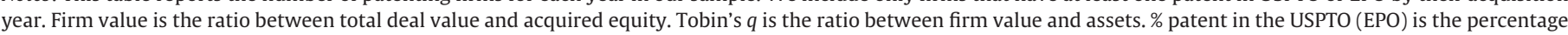
of firms that have at least one patent in the USPTO (EPO) out of all patenting firms in the same year. 
EPO patents may in part drive our results, we will also compare the estimates $\beta_{1}$ and $\beta_{2}$ for specifications where patents are weighed by citations and specifications where patents are not weighed by citations. $^{13}$

There are a number of important potential biases that may affect our estimations which are worth discussing before presenting the results.

A feature of our sample is that its firm composition changes from one year to another. This leaves our results sensitive to unobserved heterogeneity bias. A concern might be, for instance, that firms that choose to patent in the EPO in the late sample period may be, on average, of higher (unobserved) quality than firms that patent in the EPO in the beginning of the sample period. This means that later in the sample period the correlation between EPO patents and unobserved firm quality is positive, causing an upward bias in $\beta_{2}$. We can check whether this concern is likely to affect our estimates by comparing observed deal characteristics for early and later EPO patentees. For firms that patent in the EPO in the first estimation period, 1985-1990, average deal value is $\$ 395$ million, Tobin's $q$ is 2.9 , sales are $\$ 242$ million, and profits are $\$ 63$ million. For firms that patent in the EPO in the last sample period (2005-2007), average value is lower at $\$ 370$ million, but Tobin's $q$ is higher at 4.2. Sales are similar to the early period level at 229 , but profits are much lower at $\$ 33$ million. From this comparison, it is not clear whether earlier EPO patentees are of lower quality than later ones. Interestingly, we do find that that later EPO patentees benefit from higher Tobin's $q$ as compared to early EPO patentees. This is consistent with the view that knowledge assets for these firms account for a greater portion of firm value. Our estimation results which are presented below are consistent with this interpretation.

Another potential source of sample selection is industry composition. In the later period of the sample we observe more biotechnology and information technology acquisitions than in earlier periods. If the impact of patents on firm valuation varies across industries, then our key estimates could be biased. Controlling for industry is also important because, as our discussion suggests, patent quality may have declined more in some industries than others. To check the sensitivity of our results to industry variation, we report our main estimation results separately for the main innovative industries in our sample. ${ }^{14}$

Lastly, we observe a sharp decline in the share of American targets in our sample. While in the early periods about 50 percent of targets are American, this percentage drops to about 20 percent in the late sample periods. A similar pattern emerges when looking at patenting firms only (from 60 to 30 percent). This could affect our results, for instance if USPTO patents matter mostly to American firms, but also non-American firms patent at the USPTO. Thus, when presenting the econometric results, we also discuss the robustness of our findings to splitting the sample between American and non-American targets.

\footnotetext{
13 An important caveat is in order. A premise of our analysis is that patent citations are a useful proxy for patent quality. However, because the citations a patent receives accumulate over time, patent quality is likely to be measured with error toward the end of the estimation period. If the EPO provides some quality reassurance because few "bad" patents are granted by the EPO, then $\beta_{2}$ is likely to be higher (and $\beta_{1}$ lower) in the last years of the estimation period even if patents are weighted by citations, simply because of citation-truncation. Yet, finding that USPTO patents become less valuable before the end of the estimation period (as we do, see Table 5, columns 4-5 and 10-11) suggests that truncation is not likely to completely drive our results.

14 We also checked how the representation of different industries changes throughout our sample period. We focused on drugs and chemicals because patenting is very important in these industries; thus changes in representation over time have the potential to affect our estimates. We did not find substantial variation in the representation of these industries in our sample over time. In 1985, 4.6\% of the deals are in drugs and chemicals. In 2007 , the proportion is $5.0 \%$.
}

\section{Estimation results}

\section{1. "Horse-race" estimation}

Table 4 reports the estimation results for the complete sample period. We start with patent measures not weighed by citations (thus, we use the number of patents each firm holds when constructing the EPO and USPTO patent stocks). Column 1 includes logged total patent stock (the log of the sum of USPTO and EPO patent stocks). The elasticity estimate of acquisition value with respect to total patent stock is 0.117 (a standard error of 0.007 ). Obtaining an elasticity estimate allows us to calculate the increase in acquisition value as a response to a unitary increase in patent stock. For this computation, we use the average acquisition value and average patent stock values for patenting firms in the sample. The elasticity estimate from column 1 implies that increasing total patent stock by one is associated with a $\$ 1.2$ million increase in acquisition value.

Columns 2 and 3 add the stocks of USPTO and EPO patents separately. In both cases the coefficient estimates are large and highly significant. In column 4 we estimate a "horse-race" between USPTO and EPO patents. Including both measures in a single regression results in a drop in both coefficient estimates as compared to when each variable is separately included. When both stocks are included, the elasticity of acquisition value with respect to EPO patents is almost twice as large as the elasticity with respect to USPTO patents. Based on the estimates from column 4, raising the EPO patent stock by one unit is associated with a $\$ 2.6$ million increase in firm value, compared to a $\$ 0.8$ million increase for the USPTO patent stock.

Columns 5-7 report initial robustness checks for the above results. In column 5 we exclude deals in information technology and business services because patentability requirements in these fields vary substantially between the U.S. and Europe. The estimates are not sensitive to removing these industries. In column 6 we include only patenting firms to ensure that our results are not driven by comparing patenting to non-patenting firms. If selection into patenting is correlated with an omitted variable that is related to value, then our patenting variables would be upward-biased. We find the same pattern of results when focusing only on firms with at least one patent. In column 7 we include only deals that are classified as "high-tech" in SDC. Our concern here is that our estimates may be driven by comparing high-tech deals (where patent valuations may be high) to low-tech deals (where patent valuations may be low). The estimates remain stable.

Columns 8-14 present the estimation results when controlling for patent quality using forward citations. Controlling for citations proves important for USPTO patents, but much less so for EPO patents. This is expected under the assumption that USPTO patents are of greater quality heterogeneity than EPO patents. Controlling for citations increases the coefficient estimate for USPTO patents by nearly $30 \%$ (from 0.056 to 0.072 ). Our estimates imply that a unitary increase in citation-weighed EPO and USPTO patent stocks is associated with $\$ 2.3$ and $\$ 1.1$ million increase in acquisition value, respectively. These estimates still imply large differences in the value of USPTO and EPO patents; however, the difference is considerably lower than when we do not control for citations. Another interesting result is the robustness of the USPTO coefficient in columns $12-14$ where we perform the same sensitivity checks as reported in columns 5-7.

Comparing our findings to previous estimates is challenging due to the heterogeneity of methods used and the fact that we are not aware of other studies that focus on acquisition value. These caveats notwithstanding, we provide a few comparisons to leading studies in the field. First, we compare our estimates to Hall et al. (2005). Like us, they use firm value to infer patent value (however, we use acquisition value, while they use stock market 
Table 4

Patents and firm value.

\begin{tabular}{|c|c|c|c|c|c|c|c|c|c|c|c|c|c|c|}
\hline \multicolumn{15}{|c|}{ Dependent variable: $\ln$ (Firm value) } \\
\hline & $(1)$ & (2) & (3) & (4) & (5) & (6) & (7) & $(8)$ & (9) & (10) & (11) & (12) & (13) & (14) \\
\hline & \multicolumn{7}{|c|}{ Patent count (not weighed by citations) } & \multicolumn{7}{|c|}{ Patents weighed by citations } \\
\hline & All & All & All & All & Exc. IT firms & At least one patent & Only High-Tech & All & All & All & All & Exc. IT firms & At least one patent & Only High-Tech \\
\hline $\ln (1+\text { Total Patent Stock })_{t-1}$ & $\begin{array}{l}0.117^{* *} \\
(0.007)\end{array}$ & & & & & & & $\begin{array}{l}0.122^{* *} \\
(0.007)\end{array}$ & & & & & & \\
\hline $\begin{array}{l}\ln (1+\text { USPTO Patent } \\
\text { Stock })_{t-1}\end{array}$ & & $\begin{array}{l}0.117^{* *} \\
(0.008)\end{array}$ & & $\begin{array}{l}0.056^{* *} \\
(0.012)\end{array}$ & $\begin{array}{l}0.056^{* *} \\
(0.012)\end{array}$ & $\begin{array}{l}0.048^{* *} \\
(0.015)\end{array}$ & $\begin{array}{l}0.050^{* *} \\
(0.012)\end{array}$ & & $\begin{array}{l}0.125^{* *} \\
(0.008)\end{array}$ & & $\begin{array}{l}0.075^{* *} \\
(0.011)\end{array}$ & $\begin{array}{l}0.076^{* *} \\
(0.012)\end{array}$ & $\begin{array}{l}0.072^{* *} \\
(0.012)\end{array}$ & $\begin{array}{l}0.072^{* *} \\
(0.012)\end{array}$ \\
\hline $\ln (1+E P O$ Patent & & & $0.148^{* *}$ & 0.100 & $0.093^{* \prime \prime}$ & $0.090^{* \prime}$ & $0.097^{* \prime \prime}$ & & & $0.152^{* *}$ & $0.086^{* \prime \prime}$ & 0.079 & $0.080^{*}$ & $0.080^{* \prime \prime}$ \\
\hline Stock $)_{t-1}$ & & & $(0.010)$ & $(0.014)$ & $(0.014)$ & $(0.014)$ & $(0.014)$ & & & $(0.010)$ & $(0.014)$ & $(0.014)$ & $(0.014)$ & $(0.014)$ \\
\hline $\ln$ (Net assets) & $\begin{array}{l}0.713^{* *} \\
(0.004)\end{array}$ & $\begin{array}{l}0.714^{* *} \\
(0.004)\end{array}$ & $\begin{array}{l}0.715^{* *} \\
(0.004)\end{array}$ & $\begin{array}{l}0.713^{* *} \\
(0.004)\end{array}$ & $\begin{array}{l}0.727^{* *} \\
(0.005)\end{array}$ & $\begin{array}{l}0.716^{* *} \\
(0.012)\end{array}$ & $\begin{array}{l}0.710^{* *} \\
(0.005)\end{array}$ & $\begin{array}{l}0.712^{* *} \\
(0.004)\end{array}$ & $\begin{array}{l}0.714 \\
(0.004)\end{array}$ & $\begin{array}{l}0.715^{* *} \\
(0.004)\end{array}$ & $\begin{array}{l}0.713^{* *} \\
(0.004)\end{array}$ & $\begin{array}{l}0.727^{* * i} \\
(0.005)\end{array}$ & $\begin{array}{l}0.709^{* *} \\
(0.005)\end{array}$ & $\begin{array}{l}0.709^{* *} \\
(0.005)\end{array}$ \\
\hline Two-digit industry dummies & Yes & Yes & Yes & Yes & Yes & Yes & Yes & Yes & Yes & Yes & Yes & Yes & Yes & Yes \\
\hline Country target dummies & Yes & Yes & Yes & Yes & Yes & Yes & Yes & Yes & Yes & Yes & Yes & Yes & Yes & Yes \\
\hline Acquisition year dummies & Yes & Yes & Yes & Yes & Yes & Yes & Yes & Yes & Yes & Yes & Yes & Yes & Yes & Yes \\
\hline$R^{2}$ & 0.680 & 0.679 & 0.679 & 0.679 & 0.689 & 0.683 & 0.653 & 0.680 & 0.679 & 0.679 & 0.680 & 0.690 & 0.653 & 0.653 \\
\hline Observations & 30,306 & 30,306 & 30,306 & 30,306 & 26,532 & 4,643 & 24,010 & 30,306 & 30,306 & 30,306 & 30,306 & 26,532 & 24,010 & 24,010 \\
\hline
\end{tabular}

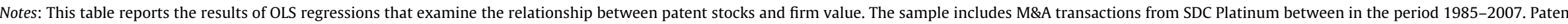

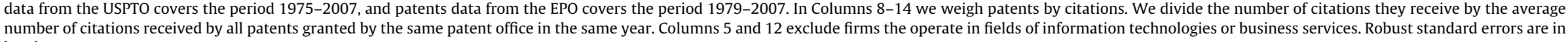
brackets.

* Significant at $5 \%$.

* Significant at 1\%. 
data). They report a citations elasticity of about 0.03 , while we find a much higher (citation-weighed) elasticity of 0.122 . It is important to note, however, that Hall et al. (2005) also control for R\&D - information which we do not have. Thus, our estimated elasticity is likely to be picking the R\&D effect as well (for instance, an increase in non-patented knowledge). Interestingly, our estimates become much closer to those of Hall et al. (2005) when considering the highly-cited patents in their sample, and actually become lower than their estimates for firms with extremely large numbers of citations per patent. Our estimates are also much higher that previous estimates obtained from patent renewal data. For example, using renewal data on European patents, Pakes (1986) and Schankerman and Pakes (1986) report very low value estimates ranging from $\$ 847$ to $\$ 19,124$ (in 1980 prices). However, the renewal approach only captures the "patent premium" - the increment to the value of an innovation which is realized by patenting it - not the overall value of a patented invention. The latter is what we measure. Estimates using renewal data may also be downward biased because extremely valuable patents may not be properly accounted for (Harhoff et al., 2003; Arora et al., 2008). Our estimates are much closer to those obtained by Gambardella et al. (2008) using the comprehensive PATVAL survey on the value of European patents. The PATVAL survey directly asked for information of the perceived value of patents, rather than trying to infer value using different estimation techniques. The authors report very high value estimates, with average patent value of above EUR10 million, and a median of EU650 thousand. Our estimates are quite close to their survey median value.

\subsection{Variation over time}

Next, we study how the value of USPTO and EPO patents has changed over time. For this purpose we estimate several "horserace" specifications for different periods in our sample. The time periods are constructed trying to even the distribution of number of deals over time, while also isolating some specific historical factors (the dot-com bubble in 1995-1998 and its burst in 2000-2001) that are evident in our descriptive statistics.

Table 5 presents the estimation results. Two specifications are provided: flexible specifications where we split the sample by periods, and specifications where we include an exhaustive set of interactions between the period dummies and USPTO and EPO patent stocks. We begin with the case when patents are not weighed by citations (columns 1-6). A clear pattern emerges. USPTO patents are important in the first sample period 1985-1990, but subsequently have no significant effect on acquisition value, except than in the dot-com bubble years 1995-1998. By contrast, the effect of EPO patents is always large and significant from 1991 to 2007 (columns 1-5).

Estimation using a pooled regression (column 6) confirms these results. EPO patents have a stable effect on value: we cannot reject the hypothesis that the EPO period interactions are different from one another $(p$-value $=0.82)$. Yet, we can strongly reject the hypothesis that they are jointly equal to zero ( $p$-value $<0.001)$. On the other hand, USPTO patents do not have a robust effect on acquisition value, and starting from 1991, with the exception of the 1995-1998 period, their effect on acquisition value is statistically zero. The importance of EPO patents, relative to USPTO patents, clearly increases over time. In the first sample period, the difference between EPO and USPTO coefficient estimates is 0.017. The same difference in the final sample period is 0.120 .

A similar pattern emerges when patents are weighed by citations (columns 7-12). USPTO patents matter for value in the first three sample periods (1985-1998), but their effect completely disappears in the 1999-2007 period. In contrast, EPO patents, which do not have a significant effect on value in the first period
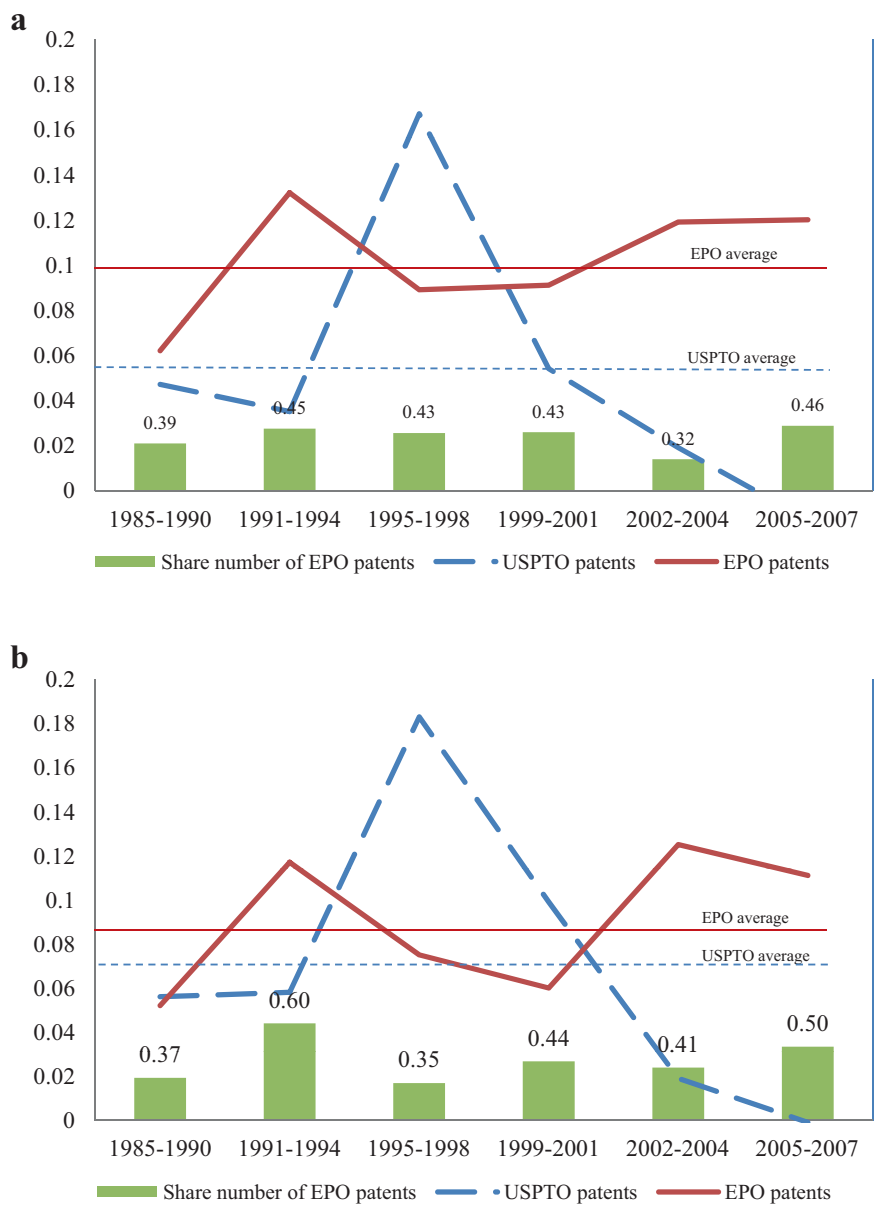

Fig. 1. (a) Time-varying coefficient estimates on USPTO and EPO patent stocks. Patents are no weighed by citations. (b) Time-varying coefficient estimates on USPTO and EPO patent stocks. Patents are not weighed by citations.

(1985-1990), become the dominant technology indicator in the late sample periods (1999-2007). ${ }^{15}$

Comparing weighed and un-weighed specifications shows that citation-weighing bolsters the effect of the USPTO patents in the early sample periods. That is what one would expect if the quality of USPTO patents is very heterogeneous. However, even in the citation-weighed specifications, the coefficient on USPTO patents drops to zero in the late sample periods. A possible explanation is that because citations accumulate over time, patent quality may be measured with large error near the end of the sample period. Thus citation-weighing may not be a particularly good way to control for patent quality in the last few years of our sample. The effect of EPO patents, by contrast, always remains very strong, both in the un-weighed and weighed regressions. Fig. 1 graphically illustrates the results from columns 6 and 12 .

Overall, the results do not support the hypothesis that stronger patent protection rights led to higher valuations for USPTO and EPO patents (Hypothesis 1). There is some evidence that EPO patents became more valuable in the last two sample periods (2002-2004 and 2005-2007); however, USPTO patent coefficients certainly did not rise. The results appear to be more consistent with the

\footnotetext{
15 Total patents stock - the sum of USPTO and EPO stocks - has a very stable effect over time (not presented in the table). The coefficient estimate on the (citationweighed) total patents stock in the period $1985-1990$ is 0.102 , compared to a value of 0.122 in the $2002-2007$ period.
} 
Table 5

Patents and firm value over time.

Dependent variable: $\ln$ (Firm value)

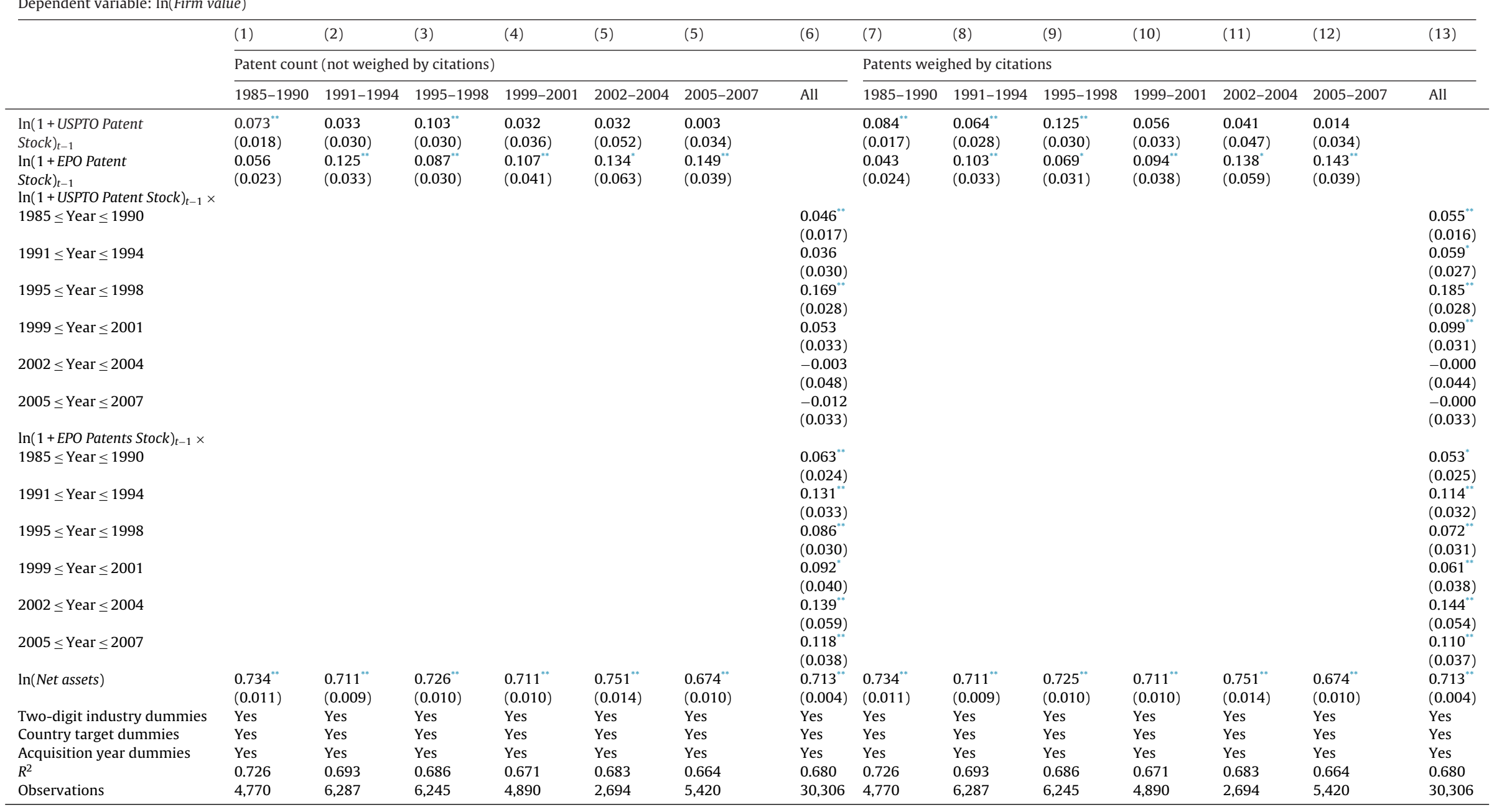

Notes: This table reports the results of OLS regressions that examine the relationship between patents and firm value in different time periods. Robust standard errors are in brackets.

* Significant at 5\%.

* Significant at 1\% 
hypothesis that USPTO patent quality and valuations declined over time (Hypothesis 2).

Using the estimates from column 13 , we can again calculate patent values for different time periods separately for USPTO and EPO patents. In the first estimation period, 1985-1990, a unitary increase in USPTO patent stock leads to a $\$ 765$ thousand increase in acquisition value. In the third period, 1995-1998, where USPTO patents seem to be the most valuable, the same unitary increase leads to a $\$ 2.8$ million rise in acquisition value. This value, however, drops to zero in the 2002-2007 period. EPO patents exhibit a much more stable correlation with acquisition value. In the first estimation period, 1985-1990, a unitary increase in the stock of EPO patents leads to a $\$ 1.4$ million increase in value. This value rises to $\$ 3.1$ million in the second period 1991-1994, which is the same value that is obtained in the last estimation period (2005-2007).

In unreported specifications, we repeated the analysis in Table 5 for patenting firms only, for firms classified as high-tech by SDC, and excluding IT and business services. The same pattern of results continues to hold. ${ }^{16}$

\section{Robustness}

The previous analysis uncovered two important findings: (i) over time, EPO patents become more valuable relative to USPTO patents, and (ii) the effect of USPTO patents on acquisition value completely disappears in the late sample periods. In this section we explore the robustness of these findings by splitting the sample according to different criteria. Due to the fewer degrees-of-freedom associated with such experimentation, the sample is split into fewer time periods.

\subsection{Target firm size}

Patents play a particularly important role in the start-up phase of a firm's life (Long, 2002). They protect young, small firms from competition by industry leaders (Teece, 1986). To potential investors, they provide "evidence that the company is well managed, is at a certain stage in development, and has defined and carved out a market niche" (Lemley, 2001, pp. 1505-1506). Not surprisingly, therefore, venture capitalists, business angels and corporate investors increasingly base their investment decisions on IP considerations (Kortum and Lerner, 2000).

Table 6 examines the extent to which our results are driven by differences in target firm size. We classify a firm as small if its sales fall in the lowest quartile of the sales distribution, and as large if its sales fall in the highest quartile. Consistent with the idea that patents matter the most for small firms, our results hold only in the small-firm sample. For large firms we find no evidence that patents (either USPTO or EPO) matter for valuation, and there is no important temporal variation in their importance. By contrast, EPO patents strongly correlate with the valuation of small firms, especially in the last sample period when they are almost as important for valuation as net assets. The effect of USPTO patents on small

\footnotetext{
16 We also more closely examine the rise in USPTO patent values during the bubble years 1995-1998. The rise in USPTO patent values is robust to removing any year in this period. For instance, when removing year 1998 (an outlier in terms of deal values as shown in Table 3), the coefficient estimate on USPTO patents (citationweighed) is 0.125 and the coefficient estimate on EPO patents is 0.063 . Splitting the sample by American and non-American targets shows that the rise in USPTO patent values is driven by non-U.S. targets. For American targets, the USPTO coefficient estimate is 0.070 ; the same estimate for non-American targets is 0.227 . Lastly, the coefficient estimate on USPTO patents is about 50\% larger in the 1995-1998 period for targets in the information technology field than in all the other industries in the same period.
}

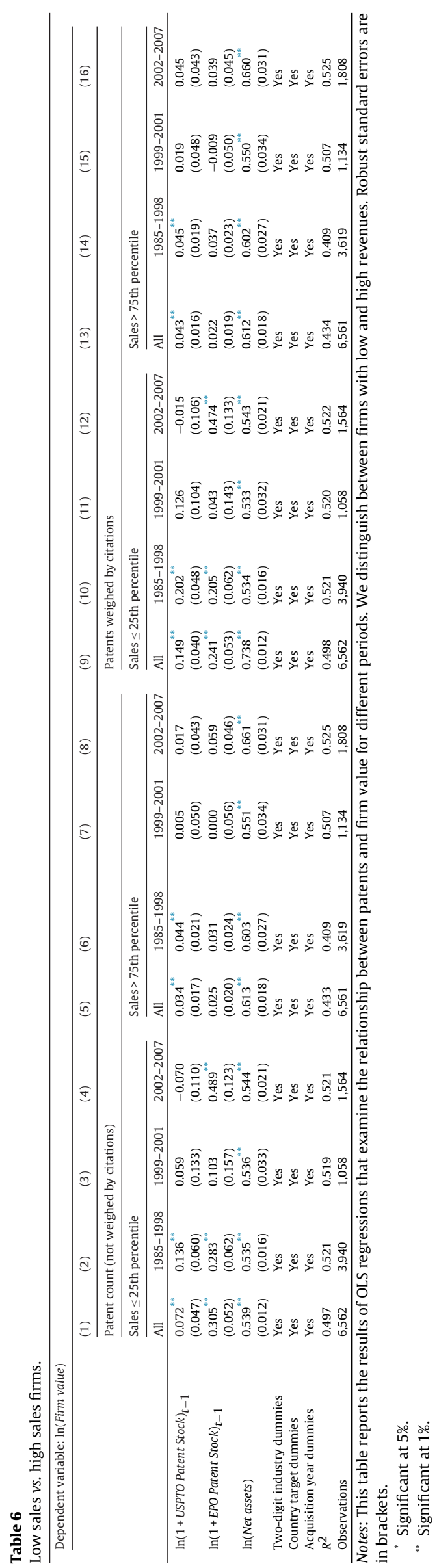


firms' acquisition value, while strong in the first sample period, subsequently disappears.

\subsection{Target-acquirer similarity}

This section explores the extent to which our findings are driven by similarities between acquiring and target firms. We focus on two dimensions of similarity: whether the acquiring and target firms operate in the same two-digit SIC code (product market similarity), and whether the acquiring and target firms operate in the same country (geographic proximity). We conjecture that, if the EPO label provides a stronger signal of quality than the USPTO label, then EPO patents should be particularly valuable, relative to USPTO patents, in between-industry and between-country deals. In these deals, in fact, asymmetric information is likely to be particularly prominent, as acquiring firms may lack specific industry knowledge or knowledge about local conditions. Thus, the quality certification provided by the EPO label may be especially valuable (Akerlof, 1970).

Tables 7 and 8 focus on product market similarity and geographic proximity, respectively. Table 7 segregates within- and between-industry acquisitions using the two-digit SIC codes of the acquiring and target firms. We find that over time EPO patents become more important, relative to USPTO patents, for betweenindustry acquisitions relative to within-industry acquisitions. This is true regardless of whether patents are weighed, although much stronger USPTO effects are obtained when patents are weighed. Table 8 segregates domestic and cross-border acquisitions. Here, USPTO patents matter only for value in domestic deals and the earlier period. By contrast, EPO patents have a strong effect on value both in domestic and cross-border acquisitions. The rise in EPO patent values, however, is particularly pronounced in cross-border acquisitions.

Overall, our findings indicate that EPO patents have become especially important in situations where asymmetric information is most likely to be substantial (i.e., between-industry and crosscountry deals). This suggests the possibility that the EPO label may provide some form of quality reassurance. Exploring this issue further is an interesting direction for future research.

\subsection{Target firm nationality}

An important concern is that our temporal patterns may be driven by changes in sample composition. Most importantly, the proportion of European targets in our sample rises substantially over time. ${ }^{17}$ If USPTO patents are less important for European firms because they mostly sell in European markets, then a pattern of declining USPTO patent values might be observed. To mitigate this concern, Table 9 splits the sample by target firm nationality (in this table patents are always weighed by citations). We find that, for American targets, USPTO patents have a large effect on value in the earlier sample period, but this effect completely disappears by the end of the sample period. EPO patents, on the other hand, experience an opposite pattern: they have no effect on value in the earlier sample period, and a large effect in the later period. For European targets, the pattern is similar. USPTO patents are only important for value in the earlier sample periods, while EPO patents have a strong and significant effect in both early and late periods (with much stronger late-period effects). Thus, our patterns - and in particular the pattern of declining USPTO effects - do not seem to be

17 There is a strong "home-bias" effect in acquisitions. 84 percent of acquisitions by American firms are American, and almost all acquisitions by European firms are European. These patterns are stable over time.

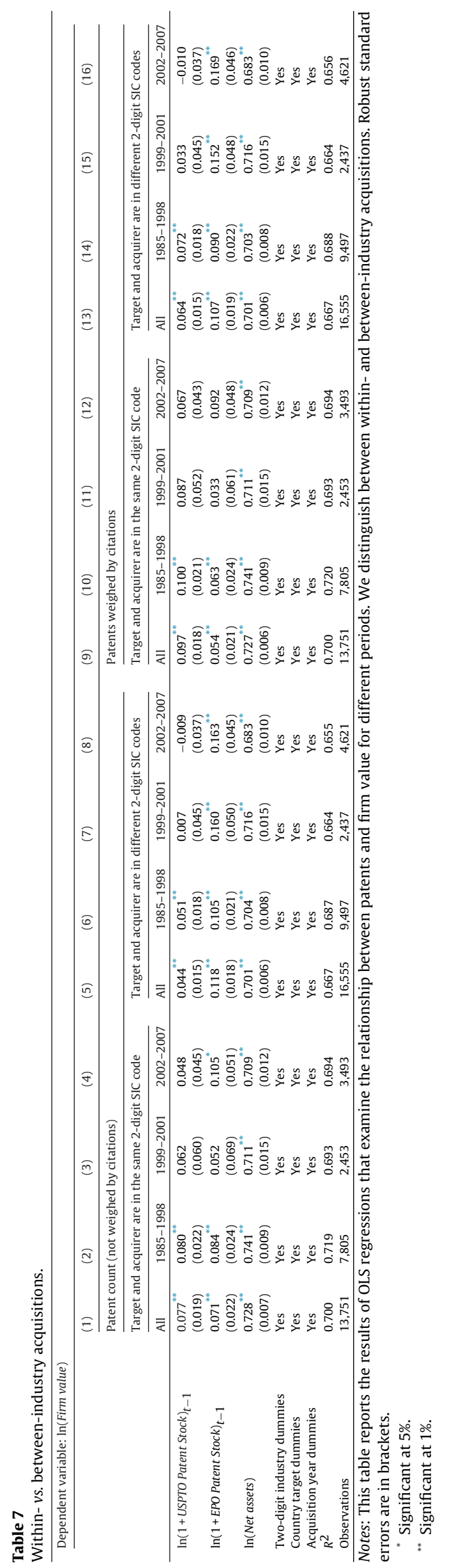


Table 8

Domestic- vs. cross-border acquisitions.

Dependent variable: $\ln$ (Firm value)

\begin{tabular}{|c|c|c|c|c|c|c|c|c|c|c|c|c|c|c|c|c|}
\hline & (1) & (2) & (3) & (4) & (5) & (6) & (7) & (8) & (9) & (10) & (11) & (12) & (13) & (14) & (15) & (16) \\
\hline & \multicolumn{8}{|c|}{ Patent count (not weighed by citations) } & \multicolumn{8}{|c|}{ Patents weighed by citations } \\
\hline & \multicolumn{4}{|c|}{ Domestic acquisitions } & \multicolumn{4}{|c|}{ Cross-border acquisitions } & \multicolumn{4}{|c|}{ Domestic acquisitions } & \multicolumn{4}{|c|}{ Cross-border acquisitions } \\
\hline & All & $1985-1998$ & 1999-2001 & $2002-2007$ & All & 1985-1998 & 1999-2001 & $2002-2007$ & All & 1985-1998 & 1999-2001 & $2002-2007$ & All & $1985-1998$ & 1999-2001 & $2002-2007$ \\
\hline $\ln (1+\text { USPTO Patent Stock })_{t-1}$ & $\begin{array}{l}0.066^{* *} \\
(0.013)\end{array}$ & $\begin{array}{l}0.067^{* *} \\
(0.015)\end{array}$ & $\begin{array}{l}.045 \\
(0.039)\end{array}$ & $\begin{array}{l}0.022 \\
(0.032)\end{array}$ & $\begin{array}{l}0.006 \\
(0.033)\end{array}$ & $\begin{array}{l}0.015 \\
(0.044)\end{array}$ & $\begin{array}{l}-0.014 \\
(0.101)\end{array}$ & $\begin{array}{l}-0.041 \\
(0.068)\end{array}$ & $\begin{array}{l}0.086 * * \\
(0.012)\end{array}$ & $\begin{array}{l}0.089^{* * *} \\
(0.014)\end{array}$ & $\begin{array}{l}0.066 \\
(0.037)\end{array}$ & $\begin{array}{l}0.034 \\
(0.031)\end{array}$ & $\begin{array}{l}0.035 \\
(0.035)\end{array}$ & $\begin{array}{l}0.043 \\
(0.049)\end{array}$ & $\begin{array}{l}0.033 \\
(0.082)\end{array}$ & $\begin{array}{l}-0.048 \\
(0.070)\end{array}$ \\
\hline $\ln (1+E P O \text { Patent Stock })_{t-1}$ & $\begin{array}{l}0.093^{* *} \\
(0.015)\end{array}$ & $\begin{array}{l}0.092^{* * 4} \\
(0.017)\end{array}$ & $\begin{array}{l}0.114 \\
(0.045)\end{array}$ & $\begin{array}{l}0.131^{* * 4} \\
(0.037)\end{array}$ & $\begin{array}{l}0.155^{* * 4} \\
(0.036)\end{array}$ & $\begin{array}{l}0.136 \\
(0.047)\end{array}$ & $\begin{array}{l}0.114 \\
(0.119)\end{array}$ & $\begin{array}{l}0.212 \\
(0.076)\end{array}$ & $\begin{array}{l}0.080 \\
(0.015)\end{array}$ & $\begin{array}{l}0.074 \\
(0.017)\end{array}$ & $\begin{array}{l}0.105^{* * 4} \\
(0.042)\end{array}$ & $\begin{array}{l}0.127^{* *} \\
(0.037)\end{array}$ & $\begin{array}{l}0.134 * * \\
(0.038)\end{array}$ & $\begin{array}{l}0.114 \\
(0.051)\end{array}$ & $\begin{array}{l}0.073 \\
(0.105)\end{array}$ & $\begin{array}{l}0.217^{* *} \\
(0.074)\end{array}$ \\
\hline $\ln ($ Net assets $)$ & $\begin{array}{l}0.718^{8} \\
(0.005)\end{array}$ & $\begin{array}{l}0.726^{* *} \\
(0.006)\end{array}$ & $\begin{array}{l}0.709^{* *} \\
(0.011)\end{array}$ & $\begin{array}{l}0.703^{* *} \\
(0.008)\end{array}$ & $\begin{array}{l}0.655^{* *} \\
(0.014)\end{array}$ & $\begin{array}{l}0.659^{* *} \\
(0.022)\end{array}$ & $\begin{array}{l}0.660^{* *} \\
(0.030)\end{array}$ & $\begin{array}{l}0.637^{* * *} \\
(0.025)\end{array}$ & $\begin{array}{l}0.717^{* *} \\
(0.005)\end{array}$ & $\begin{array}{l}0.726^{* *} \\
(0.006)\end{array}$ & $\begin{array}{l}0.709^{* * *} \\
(0.011)\end{array}$ & $\begin{array}{l}0.703^{* *} \\
(0.008)\end{array}$ & $\begin{array}{l}0.655^{* *} \\
(0.014)\end{array}$ & $\begin{array}{l}0.659^{* *} \\
(0.022)\end{array}$ & $\begin{array}{l}0.659^{* *} \\
(0.030)\end{array}$ & $\begin{array}{l}0.637^{* *} \\
(0.025)\end{array}$ \\
\hline Two-digit industry dummies & Yes & Yes & Yes & Yes & Yes & Yes & Yes & Yes & Yes & Yes & Yes & Yes & Yes & Yes & Yes & Yes \\
\hline Country & Yes & Yes & Yes & Yes & Yes & Yes & Yes & Yes & Yes & Yes & Yes & Yes & Yes & Yes & Yes & Yes \\
\hline Acquisition year dummies & Yes & Yes & Yes & Yes & Yes & Yes & Yes & Yes & Yes & Yes & Yes & Yes & Yes & Yes & Yes & Yes \\
\hline$R^{2}$ & 0.691 & 0.710 & 0.677 & 0.680 & 0.607 & 0.619 & 0.672 & 0.615 & 0.691 & 0.710 & 0.677 & 0.680 & 0.607 & 0.619 & 0.672 & 0.615 \\
\hline Observations & $\begin{array}{l}.091 \\
26,559\end{array}$ & 15,536 & $\begin{array}{l}4.091 \\
4,092\end{array}$ & $\begin{array}{l}.0000 \\
6,931\end{array}$ & $\begin{array}{l}0.007 \\
3,747\end{array}$ & $\begin{array}{l}.0 .79 \\
1,766\end{array}$ & $\begin{array}{l}7988 \\
798\end{array}$ & $\begin{array}{l}.0115 \\
1,183\end{array}$ & $\begin{array}{l}\text {. } 26,551 \\
2659\end{array}$ & $\begin{array}{l}.75,536 \\
15\end{array}$ & 4,092 & $\begin{array}{l}.0000 \\
6,931\end{array}$ & $\begin{array}{l}3.001 \\
3,747\end{array}$ & $\begin{array}{l}0.019 \\
1,766\end{array}$ & $\begin{array}{l}7988 / 2 \\
798\end{array}$ & $\begin{array}{l}. .1515 \\
1,183\end{array}$ \\
\hline
\end{tabular}

Observations

798

4,092

6,931 3,747

"Significant at 5\%.

" Significant at $1 \%$.

Table 9

American- $v$ s. European targets.

Dependent variable: $\ln \left(F_{i r m} v a(r e)\right.$

\begin{tabular}{|c|c|c|c|c|c|c|c|c|c|c|c|c|c|c|c|c|}
\hline & (1) & (2) & (3) & (4) & (5) & (6) & (7) & (8) & (9) & (10) & (11) & (12) & (13) & (14) & (15) & (16) \\
\hline & \multicolumn{8}{|c|}{ Patent count (not weighed by citations) } & \multicolumn{8}{|c|}{ Patents weighed by citations } \\
\hline & \multicolumn{4}{|c|}{ American target } & \multicolumn{4}{|c|}{ European target } & \multicolumn{4}{|c|}{ American target } & \multicolumn{4}{|c|}{ European target } \\
\hline & All & 1985-1998 & 1999-2001 & 2002-2007 & All & 1985-1998 & 1999-2001 & $2002-2007$ & All & 1985-1998 & 1999-2001 & 2002-2007 & All & 1985-1998 & 1999-2001 & 2002-2007 \\
\hline $\ln (1+\text { USPTO Patent Stock })_{t-1}$ & $\begin{array}{l}0.041^{* * *} \\
(0.016)\end{array}$ & $\begin{array}{l}0.045^{* * *} \\
(0.018)\end{array}$ & $\begin{array}{l}0.007 \\
(0.054)\end{array}$ & $\begin{array}{l}0.031 \\
(0.047)\end{array}$ & $\begin{array}{l}0.056^{* * *} \\
(0.021)\end{array}$ & $\begin{array}{l}0.069^{* * *} \\
(0.024)\end{array}$ & $\begin{array}{l}0.070 \\
(0.064)\end{array}$ & $\begin{array}{l}-0.102 \\
(0.058)\end{array}$ & $\begin{array}{l}.061 * * \\
(0.015)\end{array}$ & $\begin{array}{l}0.0711^{* *} \\
(0.017)\end{array}$ & $\begin{array}{l}0.023 \\
(0.045)\end{array}$ & $\begin{array}{l}0.036 \\
(0.042)\end{array}$ & $\begin{array}{l}0.083^{* *} \\
(0.021)\end{array}$ & $\begin{array}{l}0.095^{* *} \\
(0.024)\end{array}$ & $\begin{array}{l}0.118^{*} \\
(0.059)\end{array}$ & $\begin{array}{l}-0.123^{*} \\
(0.062)\end{array}$ \\
\hline $\ln (1+\text { EPO Patent Stock })_{t-1}$ & $\begin{array}{l}0.105^{* *} \\
(0.018)\end{array}$ & $\begin{array}{l}0.105^{* *} \\
(0.020)\end{array}$ & $\begin{array}{l}0.145^{* *} \\
(0.064)\end{array}$ & $\begin{array}{l}0.095^{*} \\
(0.055)\end{array}$ & $\begin{array}{l}0.101 * * \\
(0.025)\end{array}$ & $\begin{array}{l}0.096 * \\
(0.029)\end{array}$ & $\begin{array}{l}0.064 \\
(0.068)\end{array}$ & $\begin{array}{l}0.2166^{* *} \\
(0.059)\end{array}$ & $\begin{array}{l}0.090^{* *} \\
(0.018)\end{array}$ & $\begin{array}{l}0.084^{* *} \\
(0.020)\end{array}$ & $\begin{array}{l}0.136^{* *} \\
(0.058)\end{array}$ & $\begin{array}{l}0.096^{*} \\
(0.054)\end{array}$ & $\begin{array}{l}0.085^{* *} \\
(0.026)\end{array}$ & $\begin{array}{l}0.077^{* *} \\
(0.029)\end{array}$ & $\begin{array}{l}0.039 \\
(0.065)\end{array}$ & $\begin{array}{l}0.227^{* *} \\
(0.061)\end{array}$ \\
\hline $\ln ($ Net assets) & $\begin{array}{l}0.719^{* * *} \\
(0.007)\end{array}$ & $\begin{array}{l}0.744^{* *} \\
(0.008)\end{array}$ & $\begin{array}{l}0.648 * \\
(0.020)\end{array}$ & $\begin{array}{l}0.684 \\
(0.017)\end{array}$ & $\begin{array}{l}0.707^{* * *} \\
(0.006)\end{array}$ & $\begin{array}{l}0.6999^{* *} \\
(0.009)\end{array}$ & $\begin{array}{l}0.741^{* * *} \\
(0.013)\end{array}$ & $\begin{array}{l}0.700^{* * *} \\
(0.010)\end{array}$ & $\begin{array}{l}0.718^{* * *} \\
(0.007)\end{array}$ & $\begin{array}{l}0.742^{* *} \\
(0.008)\end{array}$ & $\begin{array}{l}0.648^{* * *} \\
(0.020)\end{array}$ & $\begin{array}{l}0.684^{* * *} \\
(0.017)\end{array}$ & $\begin{array}{l}0.707^{* *} \\
(0.006)\end{array}$ & $\begin{array}{l}0.699^{* * *} \\
(0.009)\end{array}$ & $\begin{array}{l}0.741^{* *} \\
(0.013)\end{array}$ & $\begin{array}{l}0.700^{* *} \\
(0.010)\end{array}$ \\
\hline Two-digit industry dummies & Yes & Yes & Yes & Yes & Yes & Yes & Yes & Yes & Yes & Yes & Yes & Yes & Yes & Yes & Yes & Yes \\
\hline Country target dummies & Yes & Yes & Yes & Yes & Yes & Yes & Yes & Yes & Yes & Yes & Yes & Yes & Yes & Yes & Yes & Yes \\
\hline Acquisition year dummies & Yes & Yes & Yes & Yes & Yes & Yes & Yes & Yes & Yes & Yes & Yes & Yes & Yes & Yes & Yes & Yes \\
\hline & 0.675 & 0.713 & 0.563 & 0.652 & 0.694 & 0.697 & 0.739 & 0.688 & 0.676 & 0.713 & 0.563 & 0.652 & 0.694 & 0.697 & 0.740 & 0.688 \\
\hline Observations & 12,001 & 8,170 & 1.866 & 1.965 & 14.655 & 8.067 & 2,476 & 4.112 & 12.001 & 8,170 & 1.866 & 1,965 & 14,655 & 8,067 & 2,476 & 4,112 \\
\hline
\end{tabular}

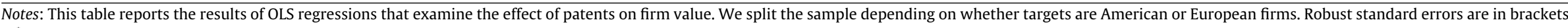

* Significant at $5 \%$.

** Significant at 1\%. 
driven by the growing proportion of European target firms in our sample. ${ }^{18}$

\subsection{Industry variation}

Patent protection varies considerably across industries. This variation can be driven by different legal patentability requirement or by differences in the nature of technology. To examine how the relationship between firm value and patents varies across industries, we separately estimate our main specification for the following industries: drugs and chemicals, electronics and computers, and prepackaged software. Drugs and chemicals are industries where patent protection is very important. Electronics and computers are industries where innovation tends to require the integration of many different pieces of knowledge and is often incremental, with follow-up developments often rapidly displacing existing products. Pre-packaged software is an interesting industry because patentability requirements vary substantially between the United States and Europe. While in the U.S. advances in IT can be easily patented, the patentability requirements for software are much stricter in Europe, regardless of the quality of the invention.

The estimation results are summarized in Table 10. For target firms that belong to the drug and chemical industries (columns $1-3$ ), our main findings are supported. In these industries, EPO patents become more important over time, while the effect of USPTO patents collapses in the late sample period. In computers and electronics, by contrast, both USPTO and EPO patents appear to matter for value, with USPTO patent coefficients having more precise estimates. In software, neither USPTO nor EPO patents appear to matter for value. Thus, our results appear to be driven by the drug and chemical sectors.

To better understand this result, we attempted to isolate the contribution of the biotechnology sector within the broader drug and chemical industries. For each of the 1390 drugs and chemicals deals in our sample, we used information from company websites and other public sources to determine whether target firms engaged in biotechnology research or production. There is a widespread perception in fact that USPTO examination standards were quite lax in new technology fields such as genomics (Merrill et al., 2004). About 40 percent of the target firms in our sample are biotechnology firms. ${ }^{19}$ Our results indicate that, although the value of USPTO patents held by biotechnology firms dropped considerably in the late sample period (from a coefficient estimate of 0.092 in column 5 to an estimate of -0.019 in column 6 ), so did the value of USPTO patents held by more traditional drugs and chemicals firms (from an estimate of 0.138 in column 8 to an estimate of 0.037 in column 9 ). Thus, our results provide little support for the conjecture that the decline in USPTO patent quality (as measured by the conditional correlation between USPTO patents and firm value) was particularly driven by the biotechnology industry, as opposed to the drug and chemical industries more generally. ${ }^{20}$

\footnotetext{
18 In unreported regressions, we also distinguish between deals where the acquirer is an American firm and deals where the acquirer is a European firm. Several interesting results emerge from this analysis. First, there is a clear pattern of declining USPTO effect, especially for acquisition where the acquiring firm is European. This pattern is not sensitive for citations weighing. Second, the effect of EPO patents is generally stable across periods, with the period 1999-2001 being an exception for European acquirers. Third, comparing early to late sample periods, the effect of EPO patents substantially increases for European acquires (from a coefficients estimate of 0.080 in 1985-1998 to an estimate of 0.221 in 2002-2007).

19 We also attempted to isolate the contribution of the genomics subfield. However, very few targets in our sample (12) belong to that subfield.

${ }^{20}$ It is important to stress, however, that we can only distinguish between biotechnology and non-biotechnology firms, not between biotechnology and nonbiotechnology patents. To the extent that traditional drugs companies possess large
}

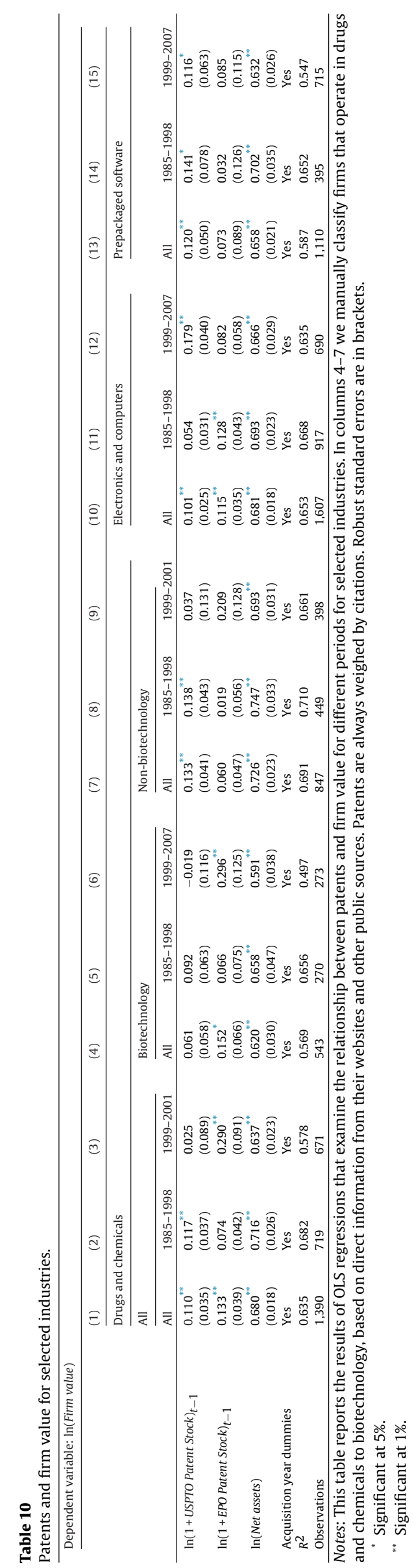




\section{Concluding remarks}

Motivated by concerns about declining patent quality standards in the U.S., this paper examines how the value of patent portfolios has changed over time. We examine more than 33,000 mergers and acquisitions deals between 1985 and 2007, and distinguish between American (USPTO) and European (EPO) patents. We find that, while the value of EPO patents has remained relatively stable over this time period, the value of USPTO patents has declined substantially and is essentially zero near the end of the sample period. Our results are robust to weighing patents by citations and are especially strong in between-industry and between-country deals, suggesting that EPO patents may provide some form of quality reassurance in transactions where asymmetric information is important.

Recent accounts of the evolution of the patent system in America and Europe offer a key to interpret these results. According to these accounts, starting from the early 1980s, patents have become much more potent legal weapons but, especially in the U.S., they have also become very easy to get (Jaffe and Lerner, 2004). Our analysis suggests that limited quality-control efforts by the USPTO, combined with the explosion of patent activity in recent years, have produced over time a very large number of USPTO patents that are essentially worthless, both economically and as a signal of technological strength. This trend may eventually have been reflected in declining patent valuations (as documented by our analysis), despite the strengthening of patent protection rights.

We stress, however, that this paper does not (and cannot) directly analyze the effect of changing IP regimes and examination standards on patent valuations. The institutional environment can influence how patents are evaluated and valued; however, several other factors also play a role. For instance, patent quality may have declined in the U.S., not because USPTO examination standards have declined, but because American firms have started to patent increasingly more marginal inventions. Since USPTO patent coefficients did not particularly drop in an industry - biotechnology - where examination standards have arguably been lax, this alternative hypothesis deserves great consideration. Changing market conditions can also have a large influence on patent valuations. In the middle of the dot-com bubble (1995-1998), we find very large estimated values for USPTO patents, arguably the result of some "irrational exuberance." We cannot exclude that the subsequent lower valuations we observe were not a reaction - and possibly an over-response - to the earlier exuberance.

Forecasting how patent values will change in the future is difficult not only because market conditions change, but also because the institutional environment is constantly evolving. A major recent reform is the America Invents Act passed by Congress in 2011. Among its most important effects, this act replaces the traditional U.S. first-to-invent system with a first-to-file system and sets up a new postgrant review process. Assessing how these changes will affect USPTO patent quality is not straightforward. On the one hand, it is likely that the new review process will improve patent quality by allowing more prior art to be brought to bear on a decision. On the other hand, some fear that a first-to-file system may give inventors strong incentives to file early, before an invention is fully developed. This may have a negative effect on patent quality.

There are three limitations to our analysis that should also be discussed. First, because our sample of firms changes from year to year, our results may be subject to unobserved heterogeneity bias. Second, patents are a territorial right: a USPTO

portfolios of biotechnology patents, our results may be subject to large measurement error. patent grants protection in the U.S., while an EPO patent potentially grants protection in a wide range of European countries. Thus, the time variation in patent valuations that we observe may be due to the changing importance of different geographical markets. Finally, globalization might have made "important" patents even more valuable (important patents being those that are granted in multiple jurisdictions). This effect might be captured by EPO patents since most firms in our sample patent in the USPTO.

While these concerns cannot entirely be dismissed, we conducted several robustness tests to mitigate them. Sections 4 and 6.3 discuss a number of problems created by changing sample composition and conclude that our results are robust. On the changing importance of geographical markets, we note that, since the 1980s, real GDP has grown faster in the U.S. than in Europe (E.U. 15). This, if anything, should have made American patents more valuable relative to EPO patents, not less. Finding the opposite makes our results more striking. In unreported regressions, we also tested the "globalization" hypothesis that patents granted in multiple jurisdictions may have become over time more valuable. We created a "globalization dummy" which receives the value of one for firms that patent in both EPO and USPTO, and zero for all other firms. Our results are robust to controlling for patenting in multiple jurisdictions.

We believe that our findings may be of interest to practitioners and researchers alike. Patent statistics are increasingly used by practitioners to evaluate companies and divisions, thanks in part to the pioneering efforts of Narin and coauthors (Deng et al., 1999; Narin, 1995). Scholars have contributed to this endeavor by providing "quality-adjusted" patent-based measures of innovative effort using citations (Trajtenberg, 1990), renewal data (Schankerman and Pakes, 1986), number of claims in a patent application (Tong and Frame, 1994), patent family size (Putnam, 1996), or combinations of the above (Lanjouw and Schankerman, 2004). This paper suggests that USPTO and EPO patents are not homogeneous in terms of their quality (economic and technical), and that average quality across jurisdictions can change substantially over time. Distinguishing between USPTO and EPO patents appears to be crucial for corporate evaluation purposes, above and beyond controlling for patent quality as measured by citations. ${ }^{21}$

Our findings are also relevant to policy-makers. Commentators have warned against the dangers of declining examination standards because, if applicants can get patents for obvious or existing ideas, then patents could be used to harass, seek compensation from, or even shut down legitimate businesses (Jaffe and Lerner, 2004). Firms may even refuse to enter some technology sectors for fear of litigation, with negative consequences for innovation and growth (Lerner, 1995). However, assessing whether and to what extent patent quality standards have actually declined has proved to be difficult (Merrill et al., 2004). This paper, by showing that USPTO patent valuations have substantially declined in a period when EPO patent valuations have remained essentially stable, may provide some impetus to current efforts to raise patent quality standards in the U.S.

\footnotetext{
21 Because patenting at the EPO is much more expensive than patenting at the USPTO, the distinction between EPO and USPTO shares some similarities with the renewal data approach. The renewal data approach assumes that patents that are renewed for longer are more valuable because patentees were willing to incur the associated renewal fees. In a similar fashion, EPO patents are likely to be on average of higher quality than USPTO patents, because EPO patentees are willing to pay substantially higher patenting costs. How much higher these costs are depends, among other factors, on the number European countries the patentee has applied for: the EPO is a unitary patent application system but not yet a unitary patent system.
} 


\section{Acknowledgements}

We thank Tim Barmby, Julian Williams and especially Ashish Arora for helpful discussions. The Editor Ben Martin, the former Editor Fiona Murray, and an anonymous referee provided extremely useful comments, which greatly improved the paper. All remaining errors are of course our own.

\section{Appendix A. Matching patent data}

We match the name of each patent applicant listed on the patent document to the full name of a firm listed in Amadeus and Icarus (about 22 million names). Our source of USPTO patents is the 2007 version of the NBER patents and citations data archive. For EPO patents, we use the 2007 publication of the PATSTAT database, which is the standard source for European patent data. This database contains all bibliographic data (including citations) on all European patent applications and granted patents, from the beginning of the EPO system in 1979 to the end of 2007.

Since we are interested only in matching patent applicants to firms, we exclude applicant names that fall into the following categories: government agencies, universities, and individuals. We identify government agencies and universities by searching for a set of identifying strings in their name. We identify individuals as patents where the assignee and the inventor name strings are identical.

The matching procedure follows two main steps. (i) Standardizing names of patent applicants. This involves replacing commonly used strings which symbolize the same thing, for example "Ltd." and "Limited" in the UK. We remove spaces between characters and transform all letters to capital letters. As an example, the name "British Nuclear Fuels Public Limited Company" becomes "BRITISHNUCLEARFUELSPLC". (ii) Name matching: match the standard names of the patent applicants with Amadeus firms. If there is no match, then try to match to the old firm name available in Amadeus. We need to confront a number of issues. First, in any given year, the Amadeus database excludes the names of firms that have not filed financial reports for four consecutive years (e.g. $M \& A$, default). We deal with this issue in several ways. First, we use information from historical versions of the Amadeus database (1995-2006) on names and name changes for European firms. Second, even though Amadeus and Icarus contain a unique firm identifier (BVD ID number), there are cases in which firms with identical names have different BVD numbers. In these cases, we use other variables for identification, for example: address (ZIP code), date of incorporation (whether consistent with the patent application date), and more. Finally, we manually match most of the remaining corporate patents to the list of Amadeus and Icarus firms.

\section{References}

Akerlof, G.A., 1970. The market for lemons: quality uncertainty and the market mechanism. Quarterly Journal of Economics 84, 488-500.

Albert, M.B., Avery, D., Narin, F., McAllister, P., 1991. Direct validation of citation counts as indicators of industrially important patents. Research Policy 20, $251-259$.

Arora, A., Ceccagnoli, M., Cohen, W.M., 2008. R\&D and the patent premium. International Journal of Industrial Organization 26, 1153-1179.

Barton, J.H., 2000. Reforming the patent system. Science 287, 1933-1934.

Belenzon, S., 2012. Cumulative innovation and market value: evidence from patent citations. Economic Journal 122, 265-285.

Bloom, N., Van Reenen, J., 2002. Patents, real options, and firm performance. Economic Journal 112, 97-116.

Deng, Z., Lev, B., Narin, F., 1999. Science and technology as predictors of stock performance. Financial Analysts Journal 55, 20-32.
Gallini, N.T., 2002. The economics of patents: lessons from recent U.S. patent reform. Journal of Economic Perspectives 16, 131-154.

Gambardella, A., Harhoff, D., Verspagen, B., 2008. The value of European patents. European Management Review 5, 69-84.

Griliches, Z., 1990. Patent statistics as economic indicators: a survey. Journal of Economic Literature 28, 1661-1707.

Guellec, D., van Pottelsberghe de la Potterie, B., 2007. The Economics of the European Patent System. IP Policy for Innovation and Competition. Oxford University Press, New York.

Hall, B.H., 2007. Patents and patent policy. Oxford Review of Economic Policy 23, 568-587.

Hall, B.H., Jaffe, A.B., Trajtenberg, M., 2005. Market value and patent citations. Rand Journal of Economics 36, 16-38

Hall, B.H., Ziedonis, R.H., 2001. The patent paradox revisited: an empirical study of patenting in the U.S. semiconductor industry, 1979-1995. Rand Journal of Economics 32, 101-128.

Harhoff, D., Narin, F., Scherer, F.M., Vopel, K., 1999. Citation frequency and the value of patented inventions. Review of Economics and Statistics 81, 511-515.

Harhoff, D., Scherer, F.M., Vopel, K., 2003. Citations, family size, opposition and the value of patent rights. Research Policy 32, 1343-1363.

Hirschey, M., Richardson, V.J., 2004. Are scientific indicators of patent quality useful to investors? Journal of Empirical Finance 11, 91-107.

Jaffe, A.B., Lerner, J., 2004. Innovation and Its Discontents: How Our Broken Patent System is Endangering Innovation and Progress, and What to Do About It. Princeton University Press, Princeton, NJ.

Kortum, S., Lerner, J., 1999. What is behind the recent surge in patenting? Research Policy 28, 1-22.

Kortum, S., Lerner, J., 2000. Assessing the contribution of venture capital to innovation. Rand Journal of Economics 31, 674-692.

Lanjouw, J.O., Lerner, J., 2001. Tilting the table? The predatory use of preliminary injunctions. Journal of Law and Economics 44, 573-603.

Lanjouw, J.O., Schankerman, M., 2004. Patent quality and research productivity: measuring innovation with multiple indicators. Economic Journal 114, 441-465.

Lemley, M.A., 2001. Rational ignorance at the patent office. Northwestern University Law Review 95, 21-56.

Lerner, J., 1995. Patenting in the shadow of competitors. Journal of Law and Economics 38, 563-595.

Lerner, J., 2002. 150 years of patent protection. American Economic Review 92 (Papers and Proceedings), 221-225.

Lesser, W., Lybbert, T., 2004. Do patents come too easy? IDEA: The Journal of Law and Technology 44, 381-407

Long, C., 2002. Patent signals. University of Chicago Law Review 69, 625-679.

Mazzoleni, R., Nelson, R.R., 1998. The benefits and costs of strong patent protection: a contribution to the current debate. Research Policy 27, 273-284.

Mejer, M., van Pottelsberghe de la Potterie, B., 2011. Patent backlogs at USPTO and EPO: systemic failure vs. deliberate delays. World Patent Information 33, $122-127$

Merges, R.P., 1992. Uncertainty and the standard of patentability. High Technology Law Journal 7, 1-70.

Merrill, S.A., Levin, R.C., Myers, M.B. (Eds.), 2004. A Patent System for the 21st Century. National Academies Press, Washington, DC.

Narin, F., 1995. Patents as indicators for the evaluation of industrial research output. Scientometrics 34, 489-496.

Narin, F., Noma, E., Perry, R., 1987. Patents as indicators of corporate technological strength. Research Policy 16, 143-215.

Pakes, A., 1985. On patents, R\&D, and the stock market rate of return. Journal of Political Economy 93, 390-409.

Pakes, A., 1986. Patents as options: some estimates of the value of holding European patent stocks. Econometrica 54, 755-784.

Putnam, J., 1996. The value of international patent rights. Ph.D. thesis. Yale University.

Quillen, C.D., Webster, O.H., 2001. Continuing patent applications and performance of the U.S. Patent and Trademark Office. Federal Circuit Bar Journal 11, 1-21.

Schankerman, M., Pakes, A., 1986. Estimates of the value of patent rights in European countries during the post-1950 period. Economic Journal 96, 1052-1076.

Slusky, A.R., Caves, R.E., 1991. Synergy, agency, and the determinants of premia paid in mergers. Journal of Industrial Economics 34, 277-296.

Teece, D.J., 1986. Profiting from technological innovation: implications for integration, collaboration, licensing and public policy. Research Policy 15, 285-305.

Thomas, P., 1999. The effect of technological impact upon patent renewal decisions. Technology Analysis and Strategic Management 1, 181-197.

Tong, X., Frame, J.D., 1994. Measuring national technological performance with patent claims data. Research Policy 23, 133-141.

Trajtenberg, M., 1990. A penny for your quotes: patent citations and the value of innovations. Rand Journal of Economics 21, 172-187.

van Pottelsberghe de la Potterie, B., François, D., 2009. The cost factor in paten systems. Journal of Industry, Competition and Trade 9, 1566-1679.

Wilson, S., 2007. Value, Protect, Exploit: How Managing Intellectual Property Can Build and Sustain Competitive Advantage. A Deloitte Research Technology, Media and Telecommunications Study, downloaded on 23 April 2013 from https://www.deloitte.com/assets/Dcom-Bulgaria/Local\%20Assets/Documents/ BG_tmt_ManagingIP_160807.pdf 